Gut, 1982, 23, 670-674

\title{
Comparison of plasma and intraluminal amino acid profiles in man after meals containing a protein hydrolysate and equivalent amino acid mixture
}

\author{
J E HEGARTY, P D FAIRCLOUGH, K J MORIARTY, M L CLARK, M J KELLY, \\ and A M DAWSON
}

From the Department of Gastroenterology, St Bartholomew's Hospital, London

SUMMARY Plasma and intraluminal amino acid profiles were compared in normal subjects 30, 60, 120, 180 minutes after meals containing either a peptide-rich protein hydrolysate $(\mathrm{H})$ or an equivalent free amino acid mixture (AA) as the nitrogen source. Except for asparagine (30 minutes) and glutamine (30 and 60 minutes), which were absorbed to a significantly $(\mathrm{p}<0.05)$ greater extent from the peptide mixture, there were no significant differences in the plasma increments of the remaining 13 amino acids at any time interval after the meals. Positive correlations ( $p<0.01$ or less) between the amino acid composition of the hydrolysate and amino acid meals and both (1) the post-prandial increments in the individual plasma amino acids and (2) the residual intraluminal amino acid content suggested that the amino acid composition of ingested protein, rather than specialised free amino acid and peptide transport systems, dictated the pattern of amino acid absorption. The studies provide no evidence that peptides rather than free amino acids are the ideal nitrogen source in elemental diets.

Protein absorption from the small intestine occurs from a mixture of free amino acids and peptides liberated from ingested protein by the sequential action of pancreatic proteases and brush border membrane peptidases. ${ }^{1}$ Amino acids and small peptides are subsequently absorbed $v i a$ specific free amino acid and peptide transport systems located within the brush border membrane of (mucosal) enterocytes. ${ }^{12}$ The role of the peptide transport system in human dietary nitrogen absorption appeared to acquire nutritional importance when several studies in $\operatorname{man}^{3-5}$ demonstrated that amino acids were absorbed to a greater extent from peptide-containing protein hydrolysates than from equivalent mixtures of free amino acids. This apparent kinetic advantage conferred by the intestinal peptide transport system, however, had been demonstrated using segmental intestinal perfusion techniques in which differences in the relative rates of amino acid absorption from peptides and comparable amino acid mixtures have recently been shown to be critically dependent on concentration. ${ }^{6}$ The present studies were designed

Received for publication 15 December 1981 to assess the differences in amino acid absorption from peptides and equivalent amino acid mixtures under more physiological conditions. Intraluminal and plasma amino acid profiles after meals containing a peptide-containing hydrolysate of lactalbumin or an equivalent mixture of free amino acids alone were compared.

\section{Methods}

The lactalbumin protein hydrolysate and equivalent amino acid mixture were prepared as previously described. $^{5}$ The hydrolysate mixture contained $20 \%$ free amino acids, $30-35 \% \mathrm{di}$, tri, and tetrapeptides, 20-30\% large oligopeptides up to 1500 Daltons and 10-20\% peptides above 1500 Daltons. The comparability of the amino acid composition of hydrolysate and amino acid mixture was checked by ion-exchange chromatography. The peptide and free amino acid meals were prepared by dissolving $50 \mathrm{~g}$ of hydrolysate and an equivalent amount $(44 \mathrm{~g})$ of amino acid mixture in $500 \mathrm{ml}$ of distilled water. The $\mathrm{pH}$ of the meals was adjusted to 7.0 by the addition of $\mathrm{NaOH}$ and the final volume adjusted to $600 \mathrm{ml}$. The meals were rendered iso-osmotic by the addition of $\mathrm{NaCl}$ to the peptide meal. The final 
osmolality of the two meals was within the range $725-800 \mathrm{mOsmol} / \mathrm{kg}$.

On the afternoon before each experiment fasting subjects were intubated with a radio-opaque double lumen tube constructed from single lumen Portex $800 / 023 / 250$ tubing. Free access to a liquid diet was then allowed until $11.00 \mathrm{pm}$. After an overnight fast the position of the tube was checked fluoroscopically to ensure that the proximal aspiration port was immediately distal to the duodenojejunal flexure and the distal port $60 \mathrm{~cm}$ distally in the small bowel. The peptide and amino acid meals were then administered in random order on separate mornings via a nasogastric tube to five normal adult volunteers (aged 19-32 years). Permission for the studies was obtained from the Ethical Committee at St Bartholomew's Hospital and informed consent obtained from all subjects.

Before, and at 30,60,120, and 180 minutes after administration of the meal $10 \mathrm{ml}$ of venous blood was collected into heparinised tubes. The plasma was immediately separated by centrifugation $(800 \mathrm{~g})$ at $4^{\circ} \mathrm{C}$ for 10 minutes and deproteinised by the addition to each millilitre of plasma of $250 \mu \mathrm{l}$ of $50 \%$ sulphosalycylic acid containing norleucine $(1 \mathrm{mmol} /$ 1) as internal standard. After mixing, the proteinfree supernatant was separated by centrifugation as above and stored at $-20^{\circ} \mathrm{C}$ until required for analysis. The concentration of 15 amino acids (Table 1) was measured in fasting and postprandial proteinfree plasmas by ion exchange chromatography using a Locarte automatic loading amino acid analyser (Locarte Company, London, UK).

Intestinal contents were obtained by simple siphonage from the two aspiration ports 60,120 , and 180 minutes after administration of the meals. The samples were placed in glass tubes in dry ice until the end of the experiment when the temperature was raised to $4^{\circ} \mathrm{C}$. After thorough mixing the samples were centrifuged $(800 \mathrm{~g})$ for 10 minutes at $4^{\circ} \mathrm{C}$. The samples were deproteinised by the procedure used for plasma and the protein-free supernatant stored at $-20^{\circ} \mathrm{C}$. An aliquot of each sample was subjected to acid hydrolysis with $6 \mathrm{M}$ $\mathrm{HCl}$ under reflux conditions at $110^{\circ} \mathrm{C}$ for 24 hours. The hydrolysed samples were then analysed by ion-exchange chromatography as above. The amino acid concentration in the intestinal aspirates after administration of the meals was then compared at the proximal and distal sampling ports 60,120 , and 180 minutes after the meals. The statistical significance of differences in amino acid plasma levels after the meals was evaluated using the Wilcoxon rank sum test for paired data $^{7}$ and correlation coefficients calculated by linear regression analysis using a Munroe-Litton calculator model 1930.

Table 1 Individual plasma amino acid increments ( $\mu \mathrm{mol} / \mathrm{ml}$ ) after administration of equal amounts of a lactalbumin hydrolysate and equivalent amino acid mixture

\begin{tabular}{|c|c|c|c|c|c|c|c|c|}
\hline & \multicolumn{8}{|c|}{ Time after meal (min) } \\
\hline & \multicolumn{2}{|l|}{30} & \multicolumn{2}{|l|}{60} & \multicolumn{2}{|l|}{120} & \multicolumn{2}{|l|}{180} \\
\hline & $\begin{array}{l}\text { Amino acid } \\
\text { mixture }\end{array}$ & $\begin{array}{l}\text { Lactalbumin } \\
\text { hydrolysate }\end{array}$ & $\begin{array}{l}\text { Amino acid } \\
\text { mixture }\end{array}$ & $\begin{array}{l}\text { Lactalbumin } \\
\text { hydrolysate }\end{array}$ & $\begin{array}{l}\text { Amino acid } \\
\text { mixture }\end{array}$ & $\begin{array}{l}\text { Lactalbumin } \\
\text { hydrolysate }\end{array}$ & $\begin{array}{l}\text { Amino acid } \\
\text { mixture }\end{array}$ & $\begin{array}{l}\text { Lactalbumin } \\
\text { hydrolysate }\end{array}$ \\
\hline Met & $42 \pm 7$ & $58 \pm 13$ & $47 \pm 7 \cdot 1$ & $61 \pm 9$ & $46 \pm 3$ & $50 \pm 9$ & $42 \pm 3$ & $48 \pm 8.5$ \\
\hline Ileu & $269 \pm 37$ & $381 \pm 64$ & $312 \pm 51$ & $460 \pm 55$ & $392 \pm 36$ & $492 \pm 45$ & $342 \pm 55$ & $389 \pm 34$ \\
\hline Leu & $360 \pm 52$ & $508 \pm 80$ & $441 \pm 61$ & $661 \pm 73$ & $497 \pm 44$ & $613 \pm 61$ & $425 \pm 59$ & $451 \pm 45$ \\
\hline Tyr & $70 \pm 22$ & $93 \pm 14$ & $61 \pm 13$ & $106 \pm 25$ & $70 \pm 12$ & $105 \pm 15$ & $106 \pm 6$ & $80 \pm 10$ \\
\hline Phe & $53 \pm 6$ & $54 \pm 13$ & $56 \pm 16$ & $62 \pm 17$ & $52 \pm 5$ & $45 \pm 16$ & $36 \pm 4$ & $40 \pm 4$ \\
\hline Lys & $321 \pm 60$ & $382 \pm 64$ & $343 \pm 53$ & $480 \pm 51$ & $354 \pm 17$ & $460 \pm 40$ & $235 \pm 24$ & $328 \pm 41$ \\
\hline His & $48 \pm 29$ & $64 \pm 22$ & $65 \pm 16$ & $84 \pm 27$ & $61 \pm 10$ & $74 \pm 20$ & $35 \pm 10$ & $17 \pm 11$ \\
\hline Arg & $125 \pm 31$ & $115 \pm 10$ & $95 \pm 32$ & $120 \pm 25$ & $90 \pm 22$ & $85 \pm 12$ & $65 \pm 21$ & $50 \pm 19$ \\
\hline Asp & $12 \pm 4^{*}$ & $23 \pm 5$ & $21 \pm 6$ & $35 \pm 8$ & $20 \pm 5$ & $24 \pm 7$ & $11 \pm 3$ & $17 \pm 4$ \\
\hline Thr & $210 \pm 48$ & $234 \pm 37$ & $264 \pm 39$ & $303 \pm 49$ & $291 \pm 28$ & $381 \pm 60$ & $295 \pm 48$ & $286 \pm 45$ \\
\hline Glu & $145 \pm 80^{*}$ & $272 \pm 48$ & $164 \pm 70$ & $279 \pm 34$ & $35 \pm 20^{*}$ & $200 \pm 35$ & $112 \pm 50$ & $130 \pm 56$ \\
\hline Pro & $233 \pm 34$ & $284 \pm 37$ & $338 \pm 68$ & $325 \pm 21$ & $338 \pm 60$ & $382 \pm 55$ & $300 \pm 66$ & $285 \pm 38$ \\
\hline Gly & $70 \pm 28$ & $60 \pm 31$ & $74 \pm 10$ & $85 \pm 38$ & $18 \pm 8$ & $36 \pm 29$ & $10 \pm 17$ & $6 \pm 12$ \\
\hline Ala & $227 \pm 50$ & $275 \pm 60$ & $225 \pm 70$ & $336 \pm 76$ & $253 \pm 56$ & $342 \pm 90$ & $154 \pm 42$ & $143 \pm 38$ \\
\hline Val & $352 \pm 52$ & $477 \pm 56$ & $462 \pm 64$ & $540 \pm 71$ & $552 \pm 40$ & $718 \pm 100$ & $559 \pm 45$ & $578 \pm 82$ \\
\hline
\end{tabular}

Values are mean of five studies \pm SEM. Increments in plasma amino acid levels were similar $(p>0.05)$ except for asparagine and glutamine ( ${ }^{*} \mathrm{p}<0.05$ or less).

Conversion factor

Individual amino acid concentration: $\mathrm{mg} / 100 \mathrm{ml}=\mathrm{Conc}(\mathrm{mmol} / \mathrm{l}) \times \mathrm{mol} \mathrm{wt}$ amino acid 


\section{Results}

PLASMA AMINO ACID LEVELS

The increases above the fasting levels of individual plasma amino acids after administration of equinitrogenous lactalbumin hydrolysate and amino acid meals are shown in Table 1 . The increase in plasma asparagine (30 minutes) and glutamine (30 and 60 minutes) was significantly ( $<<0.05$ or less) greater after administration of the hydrolysate than after the amino acid mixture. There were no significant differences in the plasma increments of the remaining 13 amino acids after the two meals. There was no significant difference in mean total plasma amino acid increments after the two meals (Table 2).

RELATIONSHIP BETWEEN INCREMENTS IN PLASMA AMINO ACIDS AND AMINO ACID COMPOSITION OF PEPTIDE AND AMINO ACID MEALS

To determine whether there was any relationship between the amino acid composition of the test meals and the postprandial increments in plasma amino acid concentration, individual plasma amino acid increments $30,60,120$, and 180 minutes after the peptide and amino acid meals were plotted against the amino acid composition of the meals. Excluding asparagine and glutamine - which are poorly absorbed and transaminated during absorption (note the small increments in plasma asparagine and glutamine (Table 2), despite their high concentration in the meals ${ }^{5}$ ) - there was a strong positive correlation between the amino acid
Table 2 Total plasma amino acid increments $(\mathrm{mmol} / \mathrm{ml})$ after administration of peptide and amino acid meals

\begin{tabular}{rlll}
\hline $\begin{array}{c}\text { Time } \\
\text { (min) }\end{array}$ & Hydrolysate & $P$ & Amino acid \\
\hline 30 & $3 \cdot 2 \pm 0 \cdot 62$ & NS & $2 \cdot 5 \pm 0.48$ \\
60 & $3 \cdot 9 \pm 0 \cdot 41$ & NS & $2 \cdot 9 \pm 0.39$ \\
120 & $4 \cdot 0 \pm 0.51$ & NS & $3 \cdot 0 \pm 0.41$ \\
180 & $2 \cdot 8 \pm 0 \cdot 58$ & NS & $2 \cdot 7 \pm 0.37$ \\
\hline
\end{tabular}

Values are mean of five studies \pm SEM.

Individual amino acid concentration:

$\mathrm{mg} / 100 \mathrm{ml}=$ Conc $(\mathrm{mmol} / \mathrm{l}) \times \mathrm{mol}$ wt amino acid

10

composition of the hydrolysate and amino acid meals and the increments in the individual plasma amino acids at each time interval studied (Figure, Table 3).

RELATIONSHIP BETWEEN RESIDUAL INTRALUMINAL AMINO ACID CONCENTRATION AND AMINO ACID COMPOSITION OF THE PEPTIDE AND AMINO ACID MEALS

The content of each individual amino acid (expressed as a percentage of total amino acids) of the intestinal samples obtained from the two aspiration ports at 60,120 , and 180 minutes after the meals was positively correlated with the amino acid composition of the meals (Table 3 ) at all time points studied. (Glycine was not included in the analysis because of the significant contribution of biliary secretions to the intraluminal glycine pool).

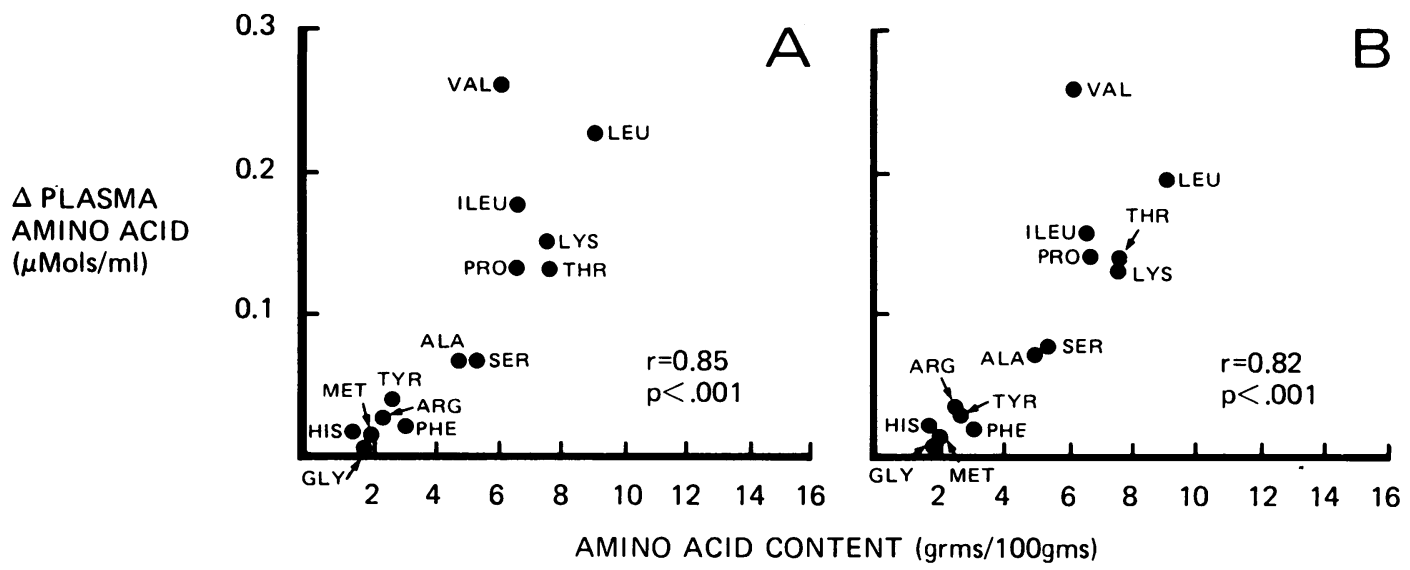

Figure Relationship between individual amino acid content of the meals and the increase in plasma amino acids 60 minutes after the hydrolysate $(A)$ and amino acid $(B)$ meals. 
Table 3 Relationship between individual amino acid concentration of meals and increase in plasma amino acid levels 30,60,120, and 180 minutes after meals containing amino acid mixture $(A A)$ or lactalbumin hydrolysate $(H)$

\begin{tabular}{|c|c|c|c|c|}
\hline & \multicolumn{4}{|c|}{ Time (min) } \\
\hline & 30 & 60 & 120 & 180 \\
\hline $\mathbf{A A}$ & $\begin{array}{l}r=0.9 \\
p<0.001\end{array}$ & $\begin{array}{l}r=0.9 \\
p<0.001\end{array}$ & $\begin{array}{l}r=0.88 \\
p<0.001\end{array}$ & $\begin{array}{l}r=0.82 \\
p<0.001\end{array}$ \\
\hline $\mathbf{H}$ & $\begin{array}{l}r=0.9 \\
p<0.001\end{array}$ & $\begin{array}{l}r=0.9 \\
p<0.001\end{array}$ & $\begin{array}{l}r=0.88 \\
p<0.001\end{array}$ & $\begin{array}{l}r=0.85 \\
p<0.001\end{array}$ \\
\hline
\end{tabular}

\section{Discussion}

The present studies demonstrate that, in subjects with normal gastrointestinal function, increments in total and individual amino acids in plasma were similar after meals containing either the lactalbumin peptide-containing hydrolysate or an equivalent mixture of free amino acids as the nitrogen source. These results contrast sharply with previous studies which emphasise differences in amino acid absorption between peptide-containing casein hydrolysates and equivalent amino acid mixtures when these were compared using the intestinal perfusion technique. ${ }^{3-6}$ Indeed, comparison of the hydrolysate used in the present study with the equivalent amino acid mixture in the perfusion system has also demonstrated significant differences in the absorption of amino acids from the two preparations. It is thus apparent that the pattern of disappearance of amino acids from the lumen seen in intestinal perfusion studies may have little bearing on the pattern of amino acids in plasma after a meal.

Table 4 Relationship between measured amino acid concentration of meals and individual amino acid content (expressed as percentage of total $A A$ ) in intestinal aspirates obtained from proximal and distal aspiration ports 60,120 , and 180 minutes after meals containing amino acid mixture $(A A)$ or lactalbumin hydrolysate $(H)$

\begin{tabular}{|c|c|c|c|c|c|c|}
\hline & \multicolumn{6}{|c|}{ Time (min) } \\
\hline & \multicolumn{3}{|l|}{ Proximal } & \multicolumn{3}{|l|}{ Distal } \\
\hline & 60 & 120 & 180 & 60 & 120 & 180 \\
\hline AA & $\begin{array}{l}r=0.81 \\
p<0.001\end{array}$ & $\begin{array}{l}r=0.73 \\
p<0.01\end{array}$ & $\begin{array}{l}r=0.86 \\
p<0.001\end{array}$ & $\begin{array}{l}r=0.72 \\
p<0.01\end{array}$ & $\begin{array}{l}r=0.76 \\
p<0.01\end{array}$ & $\begin{array}{l}r=0.79 \\
p<0.01\end{array}$ \\
\hline $\mathbf{H}$ & $\begin{array}{l}r=0.7 \\
p<0.01\end{array}$ & $\begin{array}{l}r=0.75 \\
p<0.01\end{array}$ & $\begin{array}{l}r=0.79 \\
p<0.01\end{array}$ & $\begin{array}{l}r=0.74 \\
p<0.01\end{array}$ & $\begin{array}{l}r=0.68 \\
p<0.05\end{array}$ & $\begin{array}{l}r=0.77 \\
p<0.01\end{array}$ \\
\hline
\end{tabular}

Reports of the effects of protein ingestion on the postprandial plasma amino acid profile have been conflicting. Several studies have suggested a positive relationship ${ }^{8-13}$ between the increments in plasma amino acids after a protein meal and the amino acid composition of the protein, while others ${ }^{14-16}$ have stated that no such relationship exists. These latter workers suggested that the increases in the postprandial plasma amino acids did not correlate with the amino acid composition of the meal because of a large contribution from endogenously secreted proteins, predominantly from the pancreas. This large intestinal protein load would swamp the effect of amino acids derived from ingested protein on the plasma amino acid levels. In the present study, however, the correlations between the postprandial intraluminal and plasma amino acid concentrations and the amino acid composition of the meals suggests that digestion of endogenous protein is of insufficient magnitude to obscure the contribution of the meals to postprandial intraluminal or plasma amino acids, an observation supported by the conclusions of a similar study ${ }^{8}$ comparing plasma amino acid levels after oral administration of a hydrolysate of fish protein and an eqivalent amino acid mixture. An alternative, but less likely, explanation is that endogenous protein has a similar amino acid composition to the meals we fed. The correlation between the amino acid composition of the lactalbumin preparations and the subsequent rises in the corresponding plasma amino acids after the peptide and amino acid meals further suggests that the presence of specialised amino acid and peptide transport mechanisms is unimportant compared with the amino acid composition of the meal. A possible explanation is that the concentrations of nitrogenous products in the intestinal lumen after both meals were insufficient to saturate the amino acid or peptide transport systems, so that minimal interaction or inhibition was occurring among structurally related amino acids or peptides during absorption.

The optimal composition of the nitrogen source in commercially available synthetic diets has not been established. ${ }^{17}$ The present studies provide no evidence that peptides rather than free amino acids are the ideal nitrogen source for subjects with normal gastrointestinal function. Diets containing peptides, however, are cheaper, more readily available, and also less hypertonic, which may be of benefit in reducing diarrhoea associated with enteral diets. Further studies assessing the effects of different forms of nitrogen on protein synthesis are required to establish that specialised nitrogen sources have any nutritional advantages in enteral diets. 


\section{References}

1 Matthews, D M. Intestinal absorption of peptides. Physiol Res 1975; 55: 537-608.

2 Gray, G M, Cooper H L. Protein digestion and absorption. Gastroenterology 1971; 61: 535-44.

3 Silk D B, Marrs T C, Addison J M, Burston D, Clark M L, Matthews D M. Absorption of amino acids from an amino acid mixture simulating casein and a tryptic hydrolysate of casein in man. Clin Sci 1973; 45: 715-9.

4 Silk D B, Marrs T C, Clegg K M, Addison J M, Burston D, Clark M L, Matthews D M. Jejunal absorption of an amino acid mixture simulating casein and an enzymic hydrolysate of casein prepared for oral administration to normal adults. Br J Nutr 1975; 33: 95-100.

5 Fairclough P D, Hegarty J E, Silk D B, Clark M L. Comparison of the absorption of two protein hydrolysates and their effects on water and electrolyte movement in the human jejunum. Gut 1980; 21: 829-34.

6 Hegarty J E, Moriarty K J, Fairclough P D, Clark M L, Dawson A M. Effect of concentration on amino acid absorption from a protein hydrolysate and an equivalent amino acid mixture. Gut 1982; 23: 304-9.

7 Snedecor G W, Cochrane W G. Statistical methods. Iowa: Iowa State University Press, 1937.

8 Silk D B, Chung Y C, Berger K L, Conley K, Beigler M, Sleisenger M H, Spiller G A, Kim Y S. Comparison of oral feeding of peptide and amino acids meals to normal human subjects. Gut 1979; 20: 291-9.

9 Dent C E, Schilling J A. Studies on the absorption of proteins: the amino acid profile in the portal blood. Biochem J 1949; 44: 318-34.

10 Denton A E, Elvehjem C A. Availability of amino acids in vivo. J Biol Chem 1954; 206: 449-54.

11 Richmond J, Girdwood R H. Observations on amino acid absorption. Clin Sci 1962; 22: 301-4.

12 Adibi S A, Mercer D W. Protein digestion in human intestine as reflected in luminal mucosal and plasma amino acid concentrations after meals. $J$ Clin Invest 1973; 52: 1586-94.

13 Marrs T C, Addison J M, Burston D, Matthews D M. Changes in plasma amino acid concentration in man after ingestion of an amino acid mixture simulating casein and a tryptic hydrolysate of casein. Br J Nutr 1975; 34: 259-65.

14 Frame E G. The levels of individual amino acids in the plasma of normal man at various intervals after a high protein meal. J Clin Invest 1958; 37: 1710-23.

15 Yearick E S, Nadeau R G. Serum amino acid response to isocaloric test meals. Am J Nutr 1967; 20: 338-44.

16 Nasset E S, Ju J S. Amino acid and glucose in human blood plasma after beef and non protein meals. Proc Soc Exp Biol Med 1969; 132: 1077-80.

17 Young E A, Heuler W, Russell P, Weser E. Comparative nutritional analysis of chemically defined diets. Gastroenterlogy 1975; 69: 1338-45. 